\section{SHEA/APIC AIDS Task Force}

Timothy Townsend, MD, Co-Chairperson, SHEA/APIC AIDS Task Force filed this report:

The SHEA/APIC AIDS Task Force met in Dallas, Texas, on May 5,1988 in conjunction with the APIC national convention. A large part of the task force meeting was devoted to reports of liaison activities of members with various policy-making groups such as AHA, OSHA, etc. There was considerable discussion of the issues raised at a CDC meeting in April that was attended by a task force member. The meeting at CDC had been convened to discuss possible clarifications of the CDC's A ugust $1987 \mathrm{Health}$ Care Workers' Guidelines for Universal Precautions. Although somewhat of an oversimplification of the discussions, there seemed to be two approaches to universal precautions-one that focuses on transmission of $\mathrm{HIV} / \mathrm{HBV}$ to the health care worker primarily through contact with blood or bloody body fluids, and another that focuses on transmission of a broad range of pathogens found in blood and all body fluids. The task force has contacted CDC following the May 5 task force meeting to support the concept that good infection control concepts not be lost in any clarification of the current guidelines. A report from CDC: appears in Morbidity and Mortality Werkly Report (June 24, 1988).

The brochure "AIDS Information for Health Care Workers" sponsored by SHEA and APIC and created by the task force has been sent to all SHEA and APIC members with a price list for ordering additional copies.
Comments or suggestions concerning the work of the task force can be directed to either the Neasletter or Tim Townsend (SHEA) or Steve Weinstein (APIC).

Timothy R. Townsend, MD Baltimore, Maryland

\section{Educational Activities Committee}

Donald Goldmann, MD, Chairperson, SHEA Educational Activities Committee reports that:

On April 20, SHEA sponsored a symposium entitled, "Infection Control in the Americas-Problems and Priorities." at the International Congress for Infectious Diseases in Rio de Janeiro. The co-chairpersons were Fernando Otaiza, MD of Santiago, Chile and Lee Ford-Jones, MI) of Toronto, Canada. Both persons, as well as Nalini Rao, MD of Pittsburgh, were selected by the Educational Activities Committee to receive grants in partial support for presenting posters at the symposium. The following papers were presented:

1. The Epidemiology of Nosocomial Diarrhea: A Preliminary Report. Lee Ford-Jones.

2. Cost-Effective Eradication of an Outbreak of Methicillin-Resistant Siaphylococcus aureus in a Community Teaching Hospital. Nalini Kao.

3. Prophylactic Antibiotherapy in Abdominal Surgery. A Prospective, Randomized Multicentric Study on 3,3 17 Patients. PierreI.ouis Fagniez.
4. Ceftriaxone in Prophylaxis for Head and Neck Surgery. Ricardo Durlach.

5. Colonization of Intensive Care Unit Patients with Significant Nosocomial Pathogens. Paulo Pinto, Gontijo Filho.

6. Molecular Analysis of Plasmids in Epidemiologic Investigation of Nosocomial Infections. Helio Hehl, Caiafta Filho.

7. In Vitro Antagnostic Effects of Saccharomyces boulardii against Bacteria Involved in Diarrhea in Intensive Care Unit Patients. E. BergogneBerezin.

8. Surveillance of Nosocomial Infections in Chile. Fernando Otaiza.

9. Contribution of Immediate Bacteriologic Examination and of Cell Quantitation in Broncho-alveolal Lavage in the Aclaptation of Antibiotic Treatment in Mechanically Ventilated Patients when Suspecting a Pneumopathy. A. Gerard.

Even a casual inspection of the poster titles will reveal that they did not fit easily under the umbrella of hemisphere problems and priorities. Indeed, two papers are from Europe. $\mathrm{N}$ onetheless, the co-chairpersons report good attendance and spirited discussions. SHEA participation was supported by a grant from Glaxo.

Donald Goldmann, MD Boston, Massachusetus

Bridf itrms of imterest for the SHEA Nonesteter mav be sent lo Robert A. Wornstem, MD), SHEA

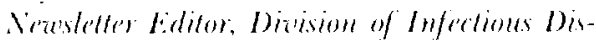
ases. Micherel Reese Hospilal. Lahe Shome

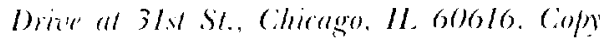
must be treed, doublespared, and mas not auced fia'e pagess. 